\title{
PSYCHE.
}

\section{HABITS AND PARASITES OF A NEW CALIFORNIAN WASP.}

\author{
BY A. DAVIDSON, M. D., LOS ANgEles, CAL.
}

While on a visit to Wilson's Peak, one of the highest mountains of the Sierra range north of Los Angeles, (5000 feet) I gathered some twigs of Nama parryi (a half shrubby perennial common on the mountain) in which some kind of wasp had burrowed, and which contained cocoons that were unfamiliar to me. The greater number of the cells were empty, but from those that remained there emerged six wasps and four parasites which $\mathrm{Mr}$. Wm. H. Ashmead kindly examined and pronounced to be new.

The cocoons are half an inch long by one-eighth of an inch wide; in shape and external appearance they closely resemble a finely-grained case of the common caddis-fly, being covered on the outer surface with a layer of fine sand, and having one end truncate while the other is rounded. The celldivisions in one specimen are composed of the pith of the plant. In the other the partitions consist of thin discs of sand. The wasp, presumably after provisioning each cell, adds a quantity of sand before sealing it up and this is afterwards utilized by the larvae in the construction of its cocoon. There are, in the Los Angeles district, at least two or three different kinds of wasps that utilize hollow stems and fill them with grains of sand to protect the larvae, but the wasp in question is peculiar in that it not only uses sand in this manner, but in addition partitions off one cell from another with it. The wasps emerged from June 22 to July 1 , about three weeks after being collected; what the larvae had fed on could not be ascertained, since there were no particles of food in any of the burrows. The parasites hatched out in the first week of July from perfect cocoons of the wasp, one from each, and obviously must have attacked the pupae. Appended is Mr. Ashmead's description of both wasp and parasite.

Odynerus rufobasilaris Ashm., sp. n.

. Length, $7 \mathrm{~mm}$. Black, coarsely rugoso-punctate, the emargination of eyes, upper margin of clypeus, and angles of the metathorax clothed with an appressed glittering pubescence. Clypeus convexly elevated, with a slight median sinus anteriorly. Mandibles and antennae entirely black, the flagellum incrassated. Anterior angles of pronotum much dilated, acute. Basal abdominal segment, except the apical margin, red; the anterior margin of pronotum (interrupted at the middle), two spots on scutellum, the hind margin of the tegulae, a spot beneath, the apical margin of the first and second dorsal segments of abdomen and the apical margin of the second ventral segment 
creamy white; legs black, with the anterior knees, more or less of their tibiae, apical half of middle and hind femora beneath and their tibiae beneath, red. Wings subfuliginous, their veins black.

Epistenia odyneri Ashm. sp. n.

9. Length, $6 \mathrm{~mm}$. Metallic green with the sides of thorax, hind coxae and first abdominal segment beneath, blue or blue green, the whole surface umbilicately punctate, clothed with a white pubescence. Flagellum beneath rufo-piceus; knees honey yellow, the tibiae and tarsi dark fuscous, almost black, the hind tibiae behind fimbriate with long stiff bristles. Wings hyaline, the veins blackish, the marginal and post marginal veins of an equal length and fully three times as long as the short stigmal vein. Abdomen conico-ovate one-third longer than the head and thorax united, with lateral carinae.

Described from one specimen bred from the cells of Odynerus rufobasilaris described above.

\section{NOTES ON THE WINTER INSECT FAUNA OF VIGO COUNTY, INDIANA.- IV.}

\section{BY W. S. BLATCHLEY, INDIANAPOLIS, INDIANA.}

As the future articles of this series will deal with the Coleoptera, and as the sandy banks of the old Wabash and Erie Canal furnished a most liberal quota of the winter hiding places for the Carabidae, as well as for the Coleoptera in general, a few words of description of these banks will not be out of place.

In the greater part of its course through Vigo County, this canal was constructed at high water mark, adjoining the river terraces on the eastern side of the Wabash River; though in but few places is it near the bed of the river, wide bottoms, cultivated in summer, intervening.

The tow path was on the river side of the canal and in many places (especially near some large ponds in the bottoms) vast beds of sand have been piled up against it by the annual freshets. On these beds of sand, drift-wood from time to time accumulates, beneath which scores of species of Coleoptera find an agreeable summer or winter home.

To the late Dr. Frederick Stein* of this city and to $\mathrm{Mr}$. H. F. Wickham of Iowa City, Iowa, I owe many of the identifications of the beetles named in this and future articles. The arrangement and nomenclature followed is that of Henshaw's "List of the Coleoptera of North America."

\section{COLEOPTERA.}

\section{Carabidae.}

Among the winter insects occurring in Vigo County no family surpasses the Carabidae in number of species, or in

* Dr. Stein died in April of last year. $\mathrm{He}$ was an enthusiastic student of Coleoptera, and his collection of that order was the largest in Indiana. 

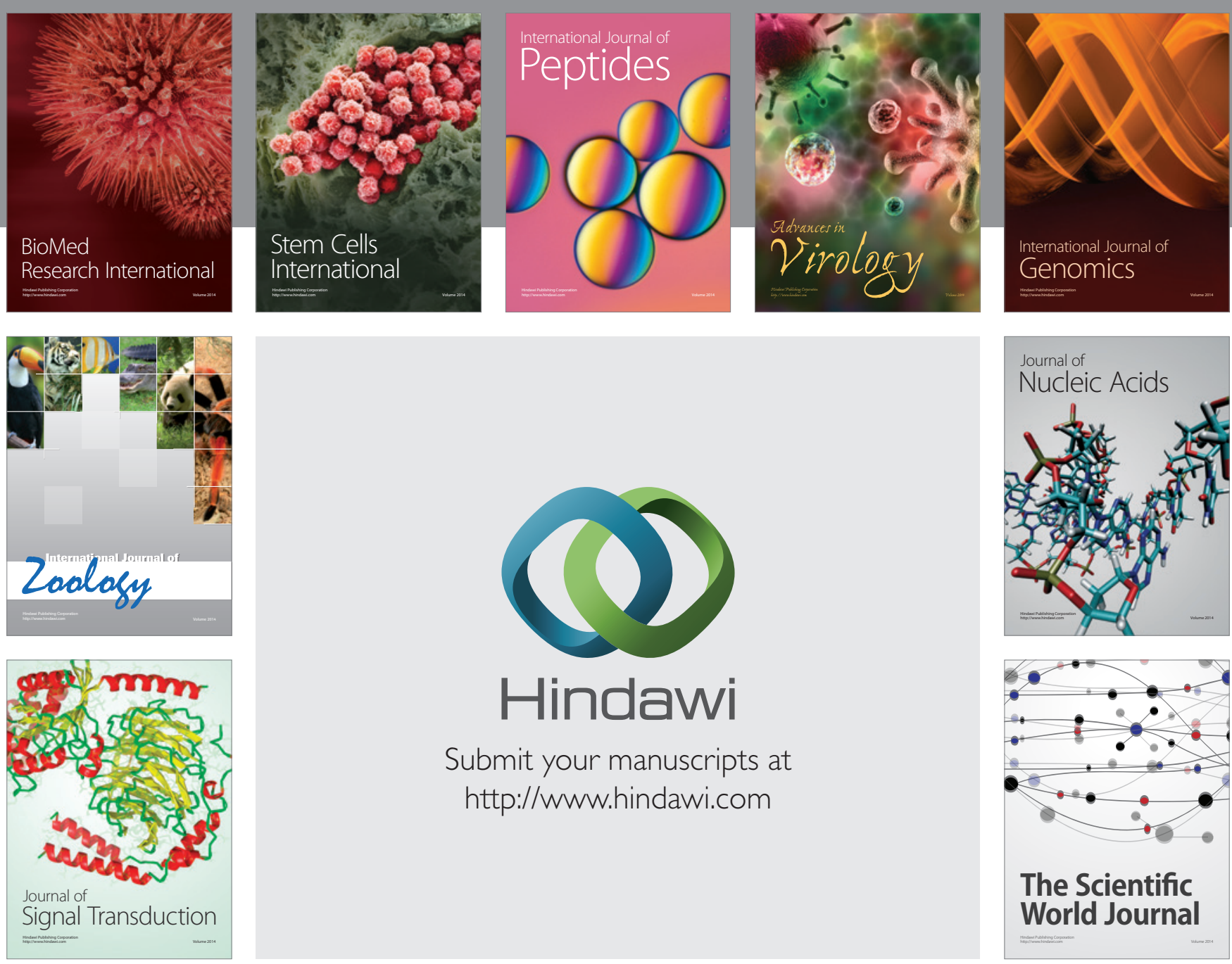

Submit your manuscripts at

http://www.hindawi.com
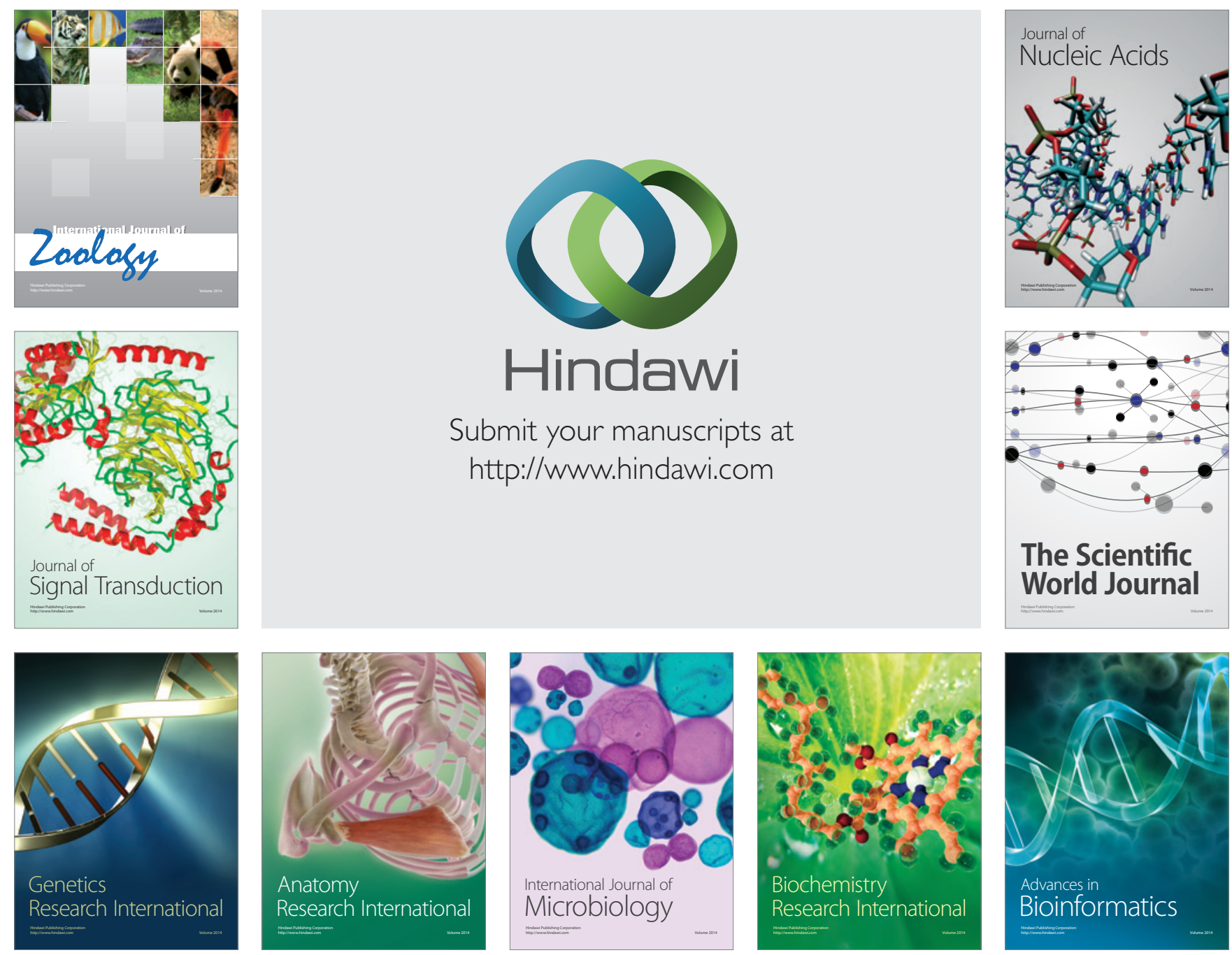

The Scientific World Journal
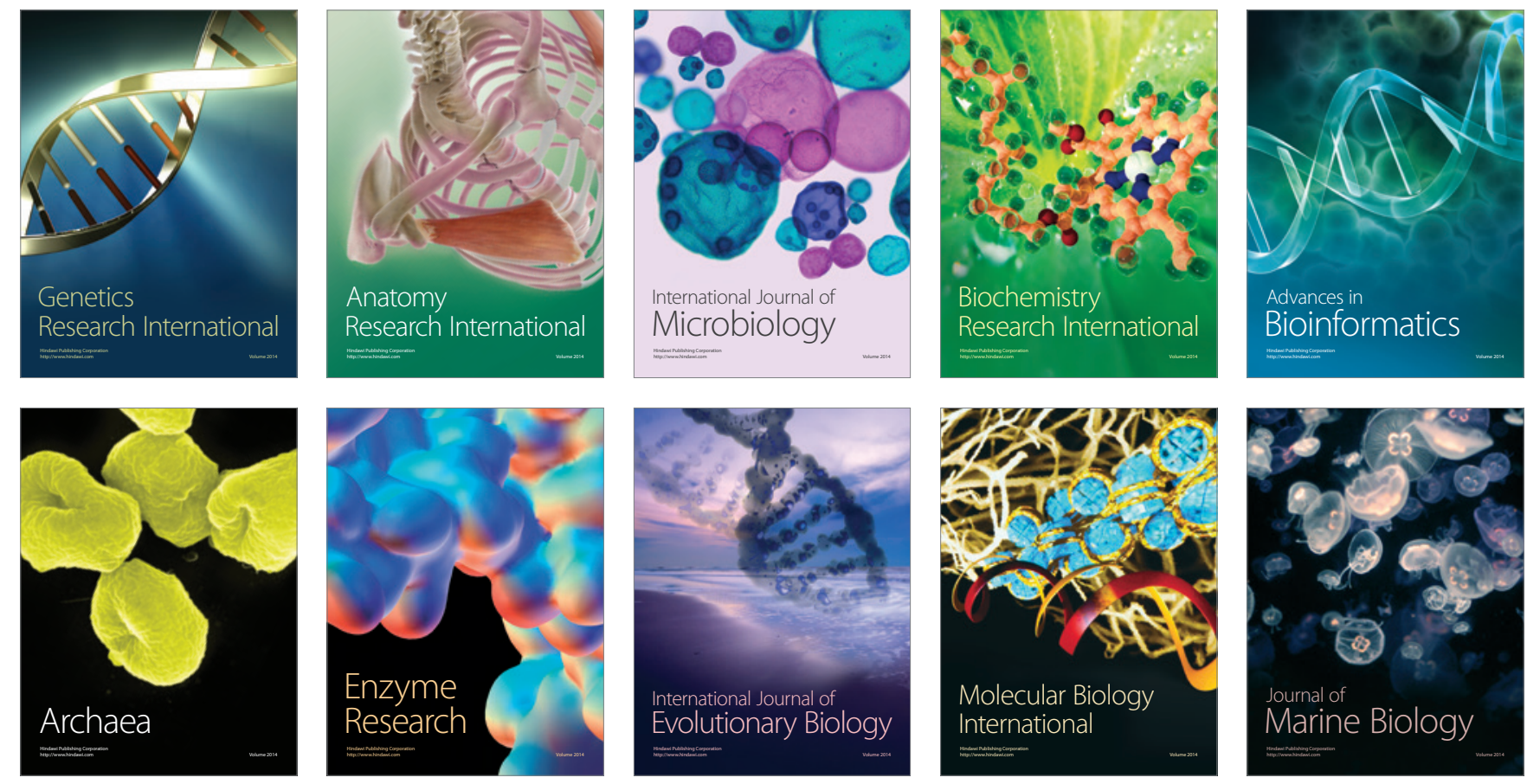